\title{
Elevational patterns of species richness and density of rattan palms (Arecaceae: Calamoideae) in Central Sulawesi, Indonesia
}

\author{
Stephanie Stiegel • Michael Kessler • Daniela Getto • \\ Joachim Thonhofer $\cdot$ Stephen F. Siebert
}

Received: 6 October 2010/Accepted: 13 May 2011/Published online: 28 May 2011

(C) The Author(s) 2011. This article is published with open access at Springerlink.com

\begin{abstract}
We studied species richness and density of rattan palms in 50 plots of $10 \times 100 \mathrm{~m}^{2}$ each between $250 \mathrm{~m}$ and $2420 \mathrm{~m}$ in eight sites in Lore Lindu National Park (LLNP), Central Sulawesi. Rattans were observed in all sample sites, representing three genera and 34 species. The elevational patterns for species richness and density were humped-shaped with maxima around $1000 \mathrm{~m}$. Polynomial models of second order explained 59 and $32 \%$ of species richness and density with the factor elevation, respectively. A majority of rattan species (65\%) overlapped between 1000 and 1100 m elevation, while a pronounced change in the rattan flora occurred above $1100 \mathrm{~m}$. Commercially important rattan species (Calamus zollingeri, C. ornatus var. celebicus, Daemonorops macroptera) were not observed above $1250 \mathrm{~m}$. The change of species assemblage was significantly related to elevation $(56 \%)$, followed by geographical distance $(47 \%)$ and precipitation $(40 \%)$. Less than $10 \%$ of LLNP is lowland forests, much of which is threatened by agricultural intensification. In contrast, montane forests are well represented in the park and high elevation forests are not subject to agricultural conversion or intensive harvesting of rattan and other forest products.
\end{abstract}

\footnotetext{
S. Stiegel $(\bowtie)$

Systematic Botany, Albrecht-von-Haller Institute of Plant Sciences, University of Göttingen, Untere Karspüle 2, 37073 Göttingen, Germany

e-mail: stephaniestiegel@gmail.com

M. Kessler

Systematic Botany, University of Zurich, Zollikerstrasse 107, 8008 Zurich, Switzerland

D. Getto

Landscape Management and Nature Conservation, University of Applied Sciences Eberswalde, Friedrich-Ebert-Str. 28, 16225 Eberswalde, Germany

J. Thonhofer

Botany and Landscape Ecology, Ernst-Moritz-Arndt-University Greifswald, Grimmer Str. 88, 17487, Greifswald, Germany

S. F. Siebert

College of Forestry and Conservation, University of Montana, Missoula, MT 59812, USA
} 
Keywords Conservation - Elevational patterns $\cdot$ Lore Lindu National Park · Non-timber forest product $\cdot$ Palms $\cdot$ Rattan $\cdot$ Species richness and density $\cdot$ Sulawesi

\section{Introduction}

Rattans belong to the palm subfamily Calamoideae and are ecologically and economically important in Asian rainforests (Gentry 1991). They are characterised by spiny stems and scaly fruits. Most rattans are lianas and climb by means of either a cirrus (an extension of the leaf rachis) or flagellum (a modified inflorescence), both of which are armed with recurved, grappling spines. Palms (Arecaceae) belong to the monocotyledonous plants whose characteristic feature is the absence of secondary growth in diameter. Therefore, their distribution is almost exclusively restricted to the tropics and subtropics because they are physiologically not able to undergo dormant periods and are hence susceptible to frosts (Tomlinson 2006). Over 600 species of rattan palms (one-fifth of all palm species) occur in Old World tropical and subtropical forests (Uhl and Dransfield 1987). Calamus is the largest genus of palms with 370-400 species (Dransfield 2001). The greatest diversity of rattan genera and species occurs in western Malesia (Dransfield and Manokaran 1994). The Indonesian island Sulawesi is located in East Malaysia and borders Wallace line. To date, 56 rattan species have been recorded from Sulawesi and 37 in Lore Lindu National Park (LLNP) in Central Sulawesi, where they account for approximately $75 \%$ of the palm flora (J. Mogea, pers. com.).

Rattan palms have been used for a wide variety of domestic, non-market purposes by rural communities for centuries (Dransfield and Manokaran 1994). In the last century, rattan canes have become one of the world's most valuable non-timber forest products (Ros-Tonen 2000). Approximately $20 \%$ of all rattan species are used commercially in the furniture industry or for matting and basketry, and in the $1970 \mathrm{~s}$ Indonesia was supplier of about $90 \%$ of the world's requirements of rattan (Dransfield and Manokaran 1994). Rattan canes are primarily collected from wild populations in primary forests (Siebert 2001). In Malaysia, Sumatra and the Philippines, most important commercial rattan species are already threatened (Sunderland and Dransfield 2002). While collecting rattan is illegal in LLNP, approximately $18 \%$ of the park was estimated subject to intensive commercial cane harvesting, particularly of Calamus zollingeri, in the late 1990s and early 2000s (Siebert 2004). In addition, virtually all of the land surrounding LLNP is influenced by human activities such as conversion of forests into agroforestry systems or plantations and harvesting of forest products (Schulze et al. 2004; Waltert et al. 2004).

Sulawesi is a poorly known but biologically important ecoregion (Cannon et al. 2007) and basic biological information on the taxonomy and ecology of the island's rattans is lacking (Clayton et al. 2002). The density and distribution of lianas in general is known to vary with abiotic factors, including elevation, annual precipitation, seasonal precipitation, soil fertility and disturbance (Balfour and Bond 1993; Gentry 1991), and this would also be expected for rattan palms. Plant species richness and changes in species composition vary markedly with elevation. Some plant groups exhibit a roughly linear decreasing richness with elevation (Acanthaceae: Kessler 2000b, Melastomataceae: Kessler 2001b), whereas others remain constant and then decline abruptly at a certain elevation (Araceae, Palmae: Kessler 2001b) or have distinctive humped-shaped patterns with maximum richness at intermediate elevations (Bromeliaceae: Kessler 2001b, ferns: Kluge et al. 2006). In general, the diversity of palms declines continuously with elevation (Bachmann et al. 2004). 
However, the density of lianas may increase with elevation (Homeier et al. 2010) and it is unknown what pattern rattan palms show. Ecological studies of rattan palms are so far limited to Thailand and West Malaysia (Bøgh 1996; Watanabe and Suzuki 2008), or have dealt with the commercially important rattan species Calamus zollingeri (Siebert 1993, 2000, 2004) and the sustainability of rattan harvesting in Sulawesi (Clayton et al. 2002). Siebert (2005), working in southern LLNP between 830 and 1330 m elevation, found that while the density of rattan did not vary significantly with elevation, species richness of rattan was greatest between 1180 and $1280 \mathrm{~m}$.

We here present the first comprehensive study of rattan species richness and density along the complete elevational amplitude of LLNP from lowland forests at $250 \mathrm{~m}$ elevation to montane forests at $2420 \mathrm{~m}$. Because our study sites were not located along a single mountain flank, we also included precipitation and spatial components in the analysis.

\section{Study area}

Lore Lindu National Park (LLNP) is located about $75 \mathrm{~km}$ south of the city of Palu in Central Sulawesi, Indonesia. The park is mountainous and about $90 \%$ of the area lies above $1000 \mathrm{~m}$ of elevation. The precipitation levels depend on elevation and topography, but mean annual precipitation can be estimated around 2000-3000 mm per year (Kessler et al. 2005). The surroundings of the national park are inhabited by more than 40,000 people who mainly live from agriculture and harvesting of non-timber forest products (The Nature Conservancy 2001, park profile). The margins of the park are characterized by a mosaic of near-primary forests, secondary forests, forest gardens and small cacao, coffee, maize and paddy rice farms (Kessler et al. 2005, 2009). Despite designation as national park, much of the forest is subject to uncontrolled extraction of forest resources, particularly rattan (Siebert 2001). In LLNP the commercially important rattan species with large stem diameter are Calamus zollingeri, C. ornatus var. celebicus and Daemonorops macroptera; other small-diameter species are gathered by the local communities for domestic purposes (local rattan collectors, pers. com.).

The eight study sites (Fig. 1) were located within LLNP (Saluki, Moa, Palili, Pono, Gunung Nokilalaki, Bariri) and outside of LLNP (Au, Gunung Rorekatimbu). Sample plots were situated randomly in natural and near-natural forest habitats at elevations between 250 and $2420 \mathrm{~m}$ (Table 1). The lowland forests of Saluki were disturbed by previous rattan collecting, but no undisturbed forests occur anywhere in the region. Human impact at higher elevations (above $1200 \mathrm{~m}$ ) was slight and limited to hunting and gathering of some forest products. In Moa and $\mathrm{Au} 90$ and $60 \%$ of the households regularly gathered stems of C. zollingeri in the late $1990 \mathrm{~s}$ (Siebert 1998). By 2000 the areas around Moa and Au had been subject to intensive cane harvesting (Siebert 2004).

\section{Methods}

Field sampling

Inventories were conducted between February and August 2008. At each study site we established sample plots of $10 \times 100 \mathrm{~m}^{2}$ which consisted of ten subplots $\left(10 \times 10 \mathrm{~m}^{2}\right)$. The sample plots were placed horizontally at one elevation within the surveyed forest area. 


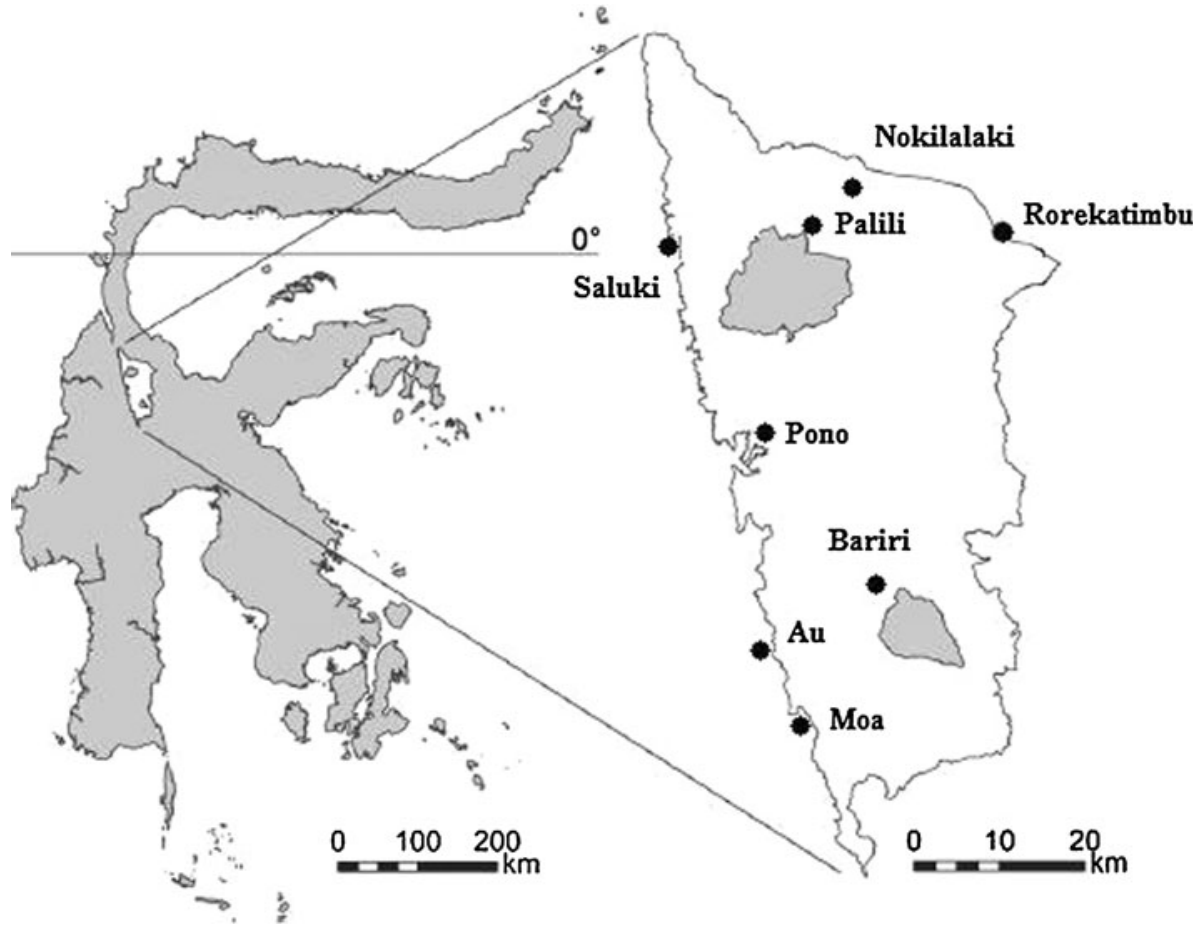

Fig. 1 Location of the eight study sites in Lore Lindu National Park, Central Sulawesi

A total number of 50 plots were sampled. Subplots were measured, marked with sticks and the following information about the rattan palms was noted: species, number of individuals (including seedlings), growth form (solitary or clustering), number of shoots per cluster and length of the stems. For the clustering rattan species (a form of vegetative propagation), a cluster was considered as an individual. Local assistants (former rattan collectors), who were familiar with the rattan palms, helped with the inventory. With their assistance the rattan species were distinguished, classified as morphospecies and labelled with their local names. For every morphospecies three voucher specimens were collected for later determination at the herbaria of Bogor (BO), Palu (CEB) and Göttingen (GOET).

Data analysis

We determined the species richness and density of rattan palms for all species and for the commercially important species at plot level $(0.1 \mathrm{ha})$. The adequacy of sampling intensity was tested with estimators after Chao (1987, formula 8). We calculated the Chao 1 index based on the species which occurred in only one or two subplots within plots and the Chao 2 index based on the species represented by only one or two individuals in the plots. Regression models were calculated for the species richness and density against the elevation and the mean annual precipitation with the software $\mathrm{R}$ (Version, 2.9.2, URL: www.r-project.org). The data for precipitation were derived from WorldClim (Hijmans et al. 2006, http://www.worldclim.org). Due to a dependent relationship between elevation 


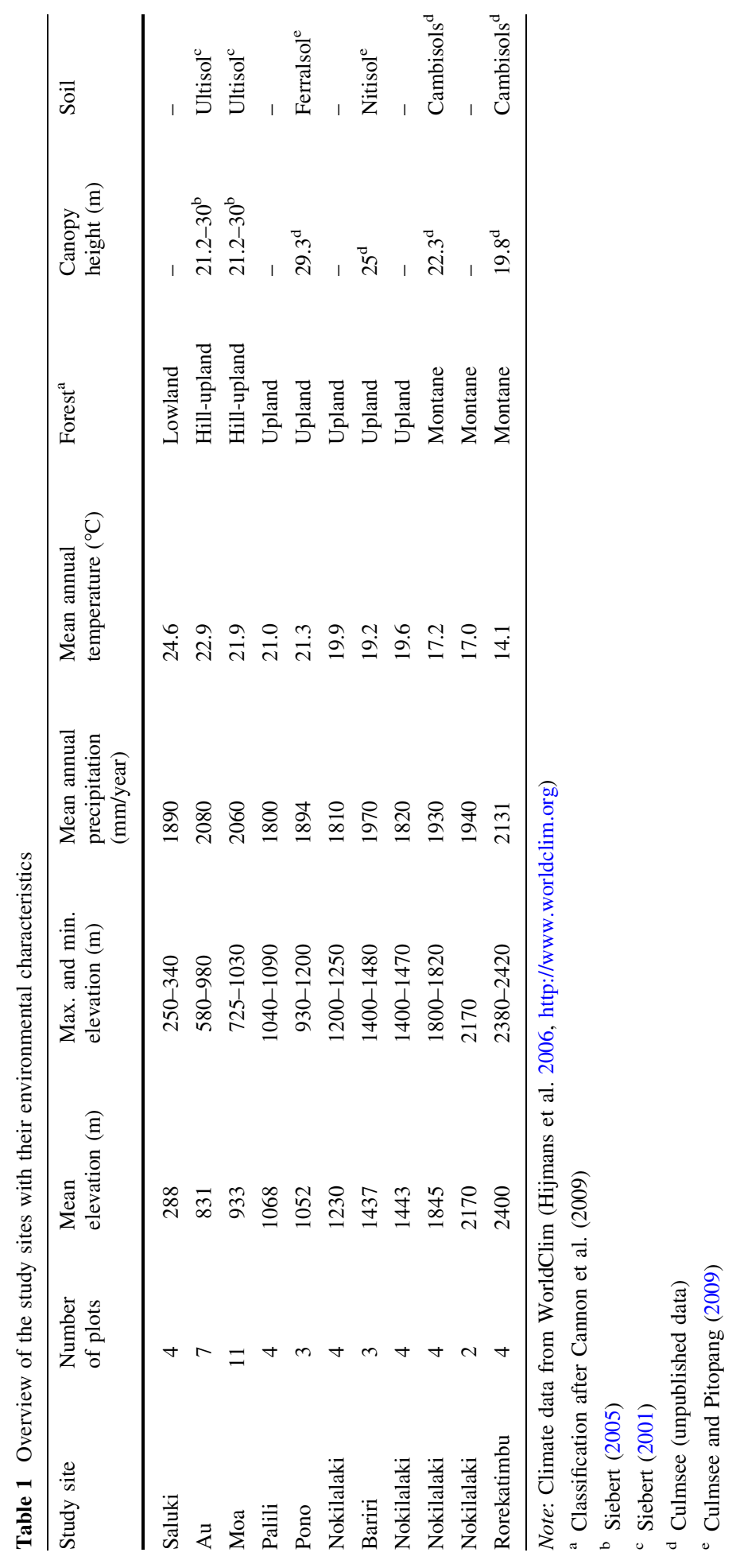


and precipitation, the residuals from the elevational models were used to assess the relationship of species richness and density to precipitation.

The elevational range of each rattan species was determined by first dividing the elevational gradient into elevational belts of $100 \mathrm{~m}$. Then, the distribution of each rattan species was assessed by its density (mean value for each elevational belt). Some elevational belts within the elevational gradient were not represented by the studied plots.

Additionally, the beta-diversity (species turnover) of rattan palms between plots was analyzed using the Sørensen index (similarity index). A distance matrix was created with PC-ORD (McCune and Mefford 1999) for the Sørensen index based on quantitative data (density of rattan species). Then, the Sørensen index was compared to the geographical distances of the plots and distance matrices of precipitation and elevation (differences between the plots) with a Mantel test. The correlation coefficient ( $r$ ) was calculated with the vegan package (Oksanen et al. 2008) in R. With the mantel function the correlation coefficients were calculated for two matrices based on 1000 permutations. Furthermore, the relationship between three matrices was tested with the mantel.partial function. This partial Mantel test is based on Legendre and Legendre (1998) and calculates the relation between two matrices (e.g. species richness and elevation) controlling for the third matrix (e.g. geographical distance). The correlation coefficient was measured for all possible combinations of the three factors (geographical distance, difference of precipitation and elevation).

\section{Results}

\section{Rattan species of LLNP}

Rattan palms were present in all 50 plots of the study sites. In total, we counted 8996 rattan individuals. Only 26 subplots $(5 \%)$ had no rattan individuals and were located in plots at Saluki (250, 260, 300 m), Gunung Nokilalaki (1200, 1220, 1400 m) and Gunung Rorekatimbu (2380, $2420 \mathrm{~m})$.

We distinguished 34 morphospecies (Appendix Table 4) of which 31 belonged to the genus Calamus, 2 to Daemonorops, and 1 to Korthalsia. Nine species could be identified to species level, whereas for the remaining 25 species only the genus is known. Eleven rattan species grew as clusters and the other 23 were solitary species.

Species richness of the study sites ranged from 3 to 15 species. At Saluki and Gunung Rorekatimbu we found 3 species, 7 at Bariri, 10 at Au, 13 at Pono and Palili, 14 at Gunung Nokilalaki, and 15 at Moa. On average 95\% (Chao 1: 93\%; Chao 2: 96\%) of the estimated species richness were found in the plots (Appendix Table 5). Hence, sampling intensities were adequate in the studied sites. The most abundant species were C. leptostachys (2559 individuals), C. sp. 5 (1032 individuals) and C. zollingeri (645 individuals). The latter species was most abundant in number of shoots (3651), followed by C. leptostachys (2561). Almost $90 \%$ of the plots were dominated by a single rattan species.

Elevational richness and density patterns

Species richness and density of the rattan palms changed markedly with elevation (Fig. 2). Maximum species richness was found at around $1000 \mathrm{~m}$. The highest overall richness with 14 rattan species was found in a plot at Moa $(890 \mathrm{~m})$. Commercially important rattan species were found only below $1250 \mathrm{~m}$ (Fig. 2a). The density of rattan palms along the elevational gradient also showed a hump-shaped pattern, with highest overall densities 

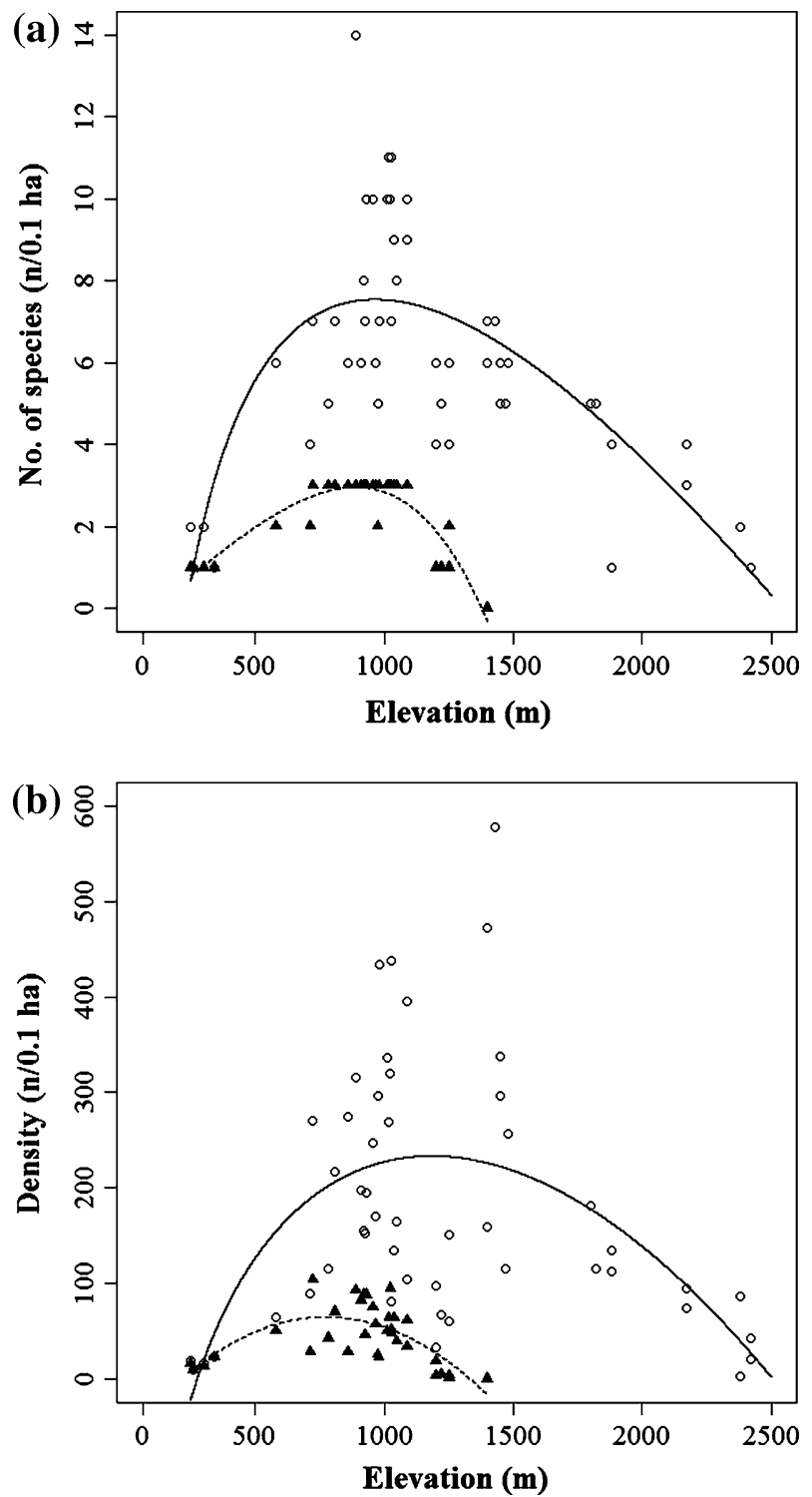

Fig. 2 a Species richness and $\mathbf{b}$ density of all rattan palms (circles, continuous lines) and commercially important rattan palms (triangles, dashed lines) in relation to elevation in Lore Lindu National Park. The commercially important rattan palms include Calamus zollingeri, $C$. ornatus var. celebicus and Daemonorops macroptera. Trend lines are polynomial models of second order as presented in Table 2

(250-500 individuals per $0.1 \mathrm{ha}$ ) around 1000-1500 m (Fig. 2b). The plot with the highest overall density of rattan palms (almost 600 individuals) was located at Gunung Nokilalaki $(1500 \mathrm{~m})$. In the lowland forests, commercially important species made up almost all of the individuals.

Polynomial models of second order accounted for 59 and $85 \%$ of the variation of overall rattan species richness and commercially important rattan species richness along the 
Table 2 Correlation between species richness and density with elevation and precipitation

\begin{tabular}{llllll}
\hline Factor & \multicolumn{2}{l}{$R^{2}$} & & & \\
\cline { 2 - 3 } & All species & & & \multicolumn{2}{l}{ Commercial species } \\
\cline { 2 - 3 } \cline { 5 - 6 } & Richness & Density & & Richness & Density \\
\hline Elevation & $0.59^{* * *}$ & $0.32^{* * *}$ & & $0.85^{* * *}$ & $0.54^{* * *}$ \\
Precipitation & 0.03 & $0.16^{*}$ & & 0.01 & 0.06 \\
\hline
\end{tabular}

The residua of the elevational models were tested against precipitation

$* P<0.05, * * * P<0.001$

elevational gradient, respectively (Fig. 2a, Table 2). For overall and commercially important rattan species densities, polynomial models accounted for 32 and $54 \%$ of the elevational patterns, respectively (Fig. 2b, Table 2). On the other hand, no significant relationships were found between species richness or density and precipitation (Table 2).

Elevational ranges of rattan species

The individual rattan species showed distinct elevational ranges (Fig. 3). Characteristic rattan palms of the forests below 1200-1300 m were mainly already described species: C. didymocarpus, C. kandariensis, C. leptostachys, C. minahassae, C. ornatus var. celebicus, C. symphysipus, C. zollingeri, D. macroptera and $K$. celebica. On the other hand, the montane forests were inhabited by mostly undescribed rattan species, although a few undescribed species were also recorded in the lowland forests. On average, elevational species ranges were $515 \pm 323(\mathrm{SD}) \mathrm{m}$, ranging from $100 \mathrm{~m}$ (7 species) to more than $1000 \mathrm{~m}$ (3 species). The majority of species were found throughout their elevational ranges, but a few species showed gaps of 100-400 m where they were not recorded.

\section{Assemblage composition}

Species turnover between plots (beta-diversity) was related to the geographical distance and the differences of precipitation and elevation between plots (Fig. 4, Table 3). While many distant plots shared some species, a difference in elevation of more than $900 \mathrm{~m}$ led to a complete change in the species set of the plots.

Accordingly, the Mantel tests showed that difference in elevation had the strongest predictive power for similarity in assemblage composition $\left(R^{2}=0.56\right)$, followed by geographical distance $\left(R^{2}=0.47\right)$ and difference in precipitation $\left(R^{2}=0.40\right)$. In combination, more than $90 \%$ of the variance of assemblage similarity was accounted for, if the difference in elevation was included. In contrast, the combination of geographical distance and difference of precipitation only accounted for $50 \%$ of the variance of assemblage similarity.

\section{Discussion}

\section{General patterns}

Rattan palms are an important component of the tropical rainforest flora in Sulawesi where they represent about 50\% (56 species) of the island's palm flora (J. Mogea, pers. com.). In our study, we found 34 species, including 25 as yet undescribed species. Complete 


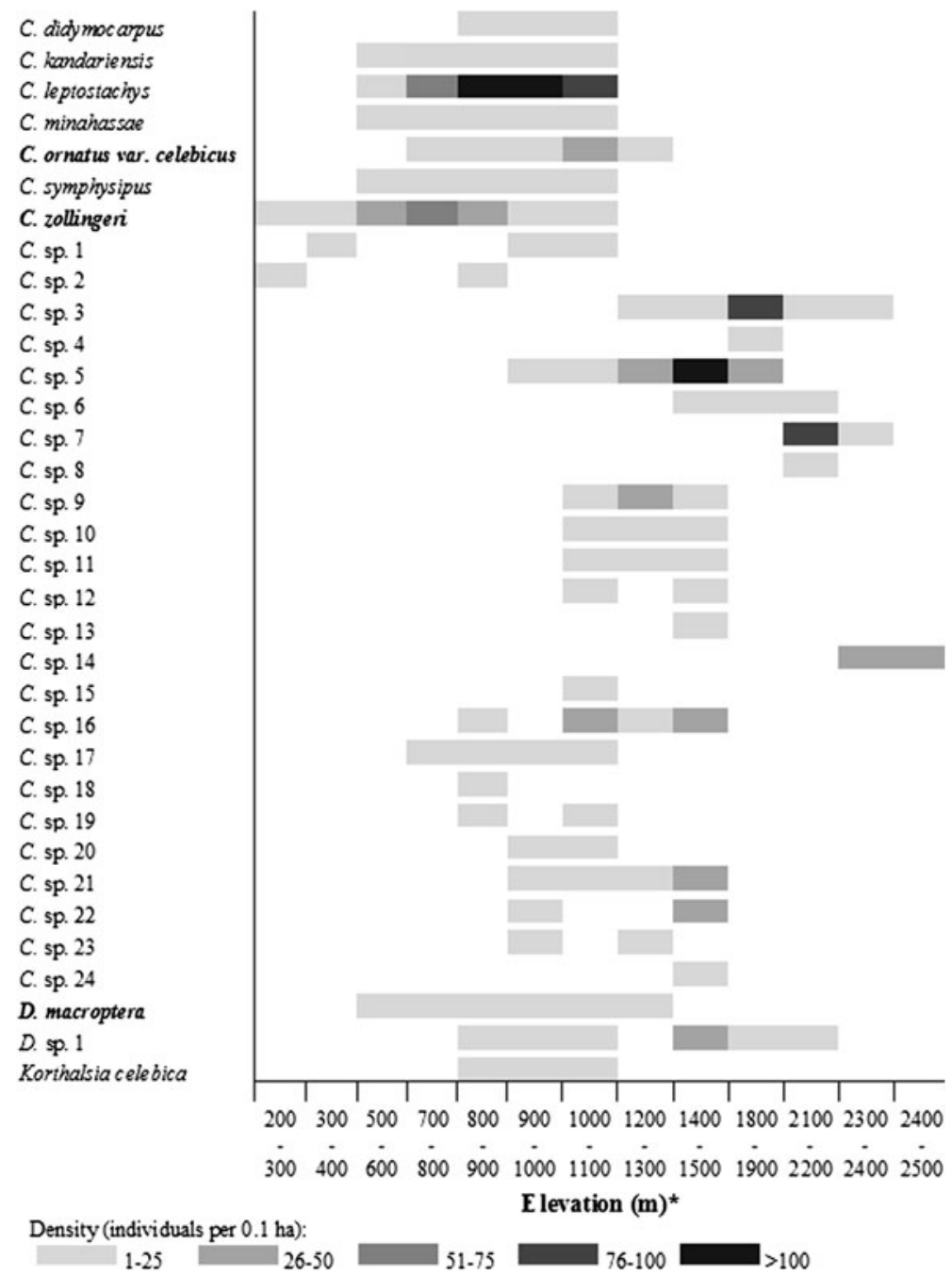

Fig. 3 Elevational ranges of rattan species recorded in Lore Lindu National Park. Elevation is divided into elevational belts of $100 \mathrm{~m}$ (*missing elevational belts have no data). Density classes are indicated by levels of grey are derived from mean values of all plots in each elevational belt. Species in boldface are commercially important. C. = Calamus, D. = Daemonorops

identification of rattan palms is often impossible without fertile specimens, which are often not available. In our study only three rattan species were found with fruits (Calamus sp. 14, Daemonorops macroptera, D. sp. 1).

Several species were widely distributed in LLNP, among them the commercially important species $C$. zollingeri, C. ornatus var. celebicus and D. macroptera. Common species of the rainforests above $1000 \mathrm{~m}$ (e.g. C. sp. 3, C. sp. 5, C. sp. 16 and D. sp. 1) are still taxonomically undescribed, reflecting the poor botanical knowledge of Sulawesi and the low economical importance of these species. Northern Borneo (Sabah, Brunei and Sarawak) harbours no fewer than 132 rattan species (Dransfield 1984, 1992, 1997), which 
Fig. 4 Beta-diversity measured as the Sørensen index dependent on the a distance, $\mathbf{b}$ difference of precipitation and $\mathbf{c}$ the difference of elevation between the plots.

A Sørensen index of 0 indicates a different composition of species
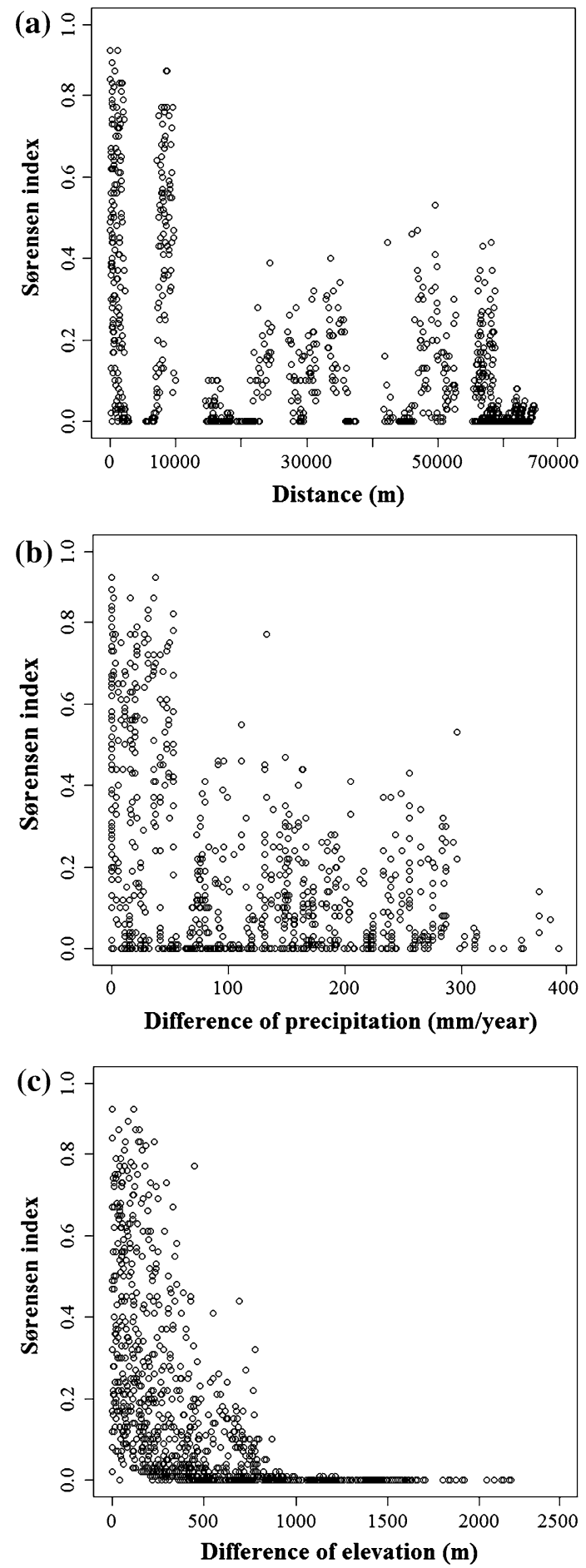
Table 3 Results of Mantel tests for correlations of Sørensen similarity index to geographical distances, differences in precipitation, and differences in elevation, as well as the combinations of these factors

\begin{tabular}{|c|c|c|c|c|c|}
\hline \multirow[t]{2}{*}{ Factor } & \multicolumn{5}{|l|}{$R^{2}$} \\
\hline & Distance & Precipitation & Elevation & Combination & Total \\
\hline Distance & 0.47 & & & & 0.47 \\
\hline Precipitation & & 0.40 & & & 0.40 \\
\hline Elevation & & & 0.56 & & 0.56 \\
\hline Distance + precipitation & 0.09 & 0.06 & & 0.35 & 0.50 \\
\hline Distance + elevation & 0.16 & & 0.24 & 0.51 & 0.91 \\
\hline Precipitation + elevation & & 0.16 & 0.32 & 0.45 & 0.93 \\
\hline
\end{tabular}

The total $R^{2}$-value of two factors is itemized into $R^{2}$-value of the single factors and their combination. All $R^{2}$-values are significant $(P<0.001)$

may suggest that this island is much more species rich in rattan palms than Sulawesi, but Borneo has been much more intensively explored botanically and the large number of undescribed species found by us shows that the rattan palm diversity of Sulawesi may be underestimated. The large proportion of species found by us at single study sites also suggests that further exploration of additional sites in LLNP will likely reveal more species, not to speak of other mountain ranges elsewhere in Sulawesi. Future sampling should also be targeted to specific sites, especially ultramafic and limestone formations due to their unique conditions and demonstrated endemism of rattan flora elsewhere (Dransfield and Manokaran 1994).

We found rattan palms in all our study plots in and around the LLNP, with species numbers per site ranging from 3 to 15. In Northern Sulawesi, 13 and 18 species were found in an unharvested lowland region and an exploited montane forest area, respectively (Clayton et al. 2002). On Borneo and Java, Watanabe and Suzuki (2008) found 14 to 17 species in mixed lowland Dipterocarp forests, while 11 species were recorded in a similar habitat in Thailand (Bøgh 1996). These values are notably higher than at our lowland site at Saluki, but this was in a relatively dry and moderately disturbed forest. On Java, Watanabe and Suzuki (2008) found 7 rattan species at mid-elevation, which is somewhat lower than the diversity found by us at Moa, Palili, and Pono at similar elevations. We conclude that the local species richness of rattan palms in the study region is in the same order of magnitude as that of other areas in Southeast Asia.

A comparison of rattan densities between studies is more complex because different studies have applied different cut-off values for the minimum size of the studied rattan individuals. Furthermore, the identification of young rattan plants is often difficult because not all of the important attributes (e.g. features of the stem) are developed.

Elevational richness and density patterns

The species richness of rattan palms in LLNP shows a humped-shaped elevational pattern with maximum richness at around $1000 \mathrm{~m}$. This pattern contrasts with that usually found in palms (Bachmann et al. 2004, Kessler 2001b), but corresponds to that found in rattan palms in Malaysia (Appanah et al. 1993) as well as in many other plant groups (e.g. Bromeliaceae: Kessler 2001b, ferns: Kluge et al. 2006). While the causes determining elevational richness patterns in plants remain poorly understood, available explanations may be grouped into four factor complexes (McCain 2009), namely (1) current climatic variables 
such as temperature and humidity (Kessler 2001a; Bhattarai et al. 2004), which in turn determine energy availability and ecosystem productivity (Hawkins et al. 2003; Currie et al. 2004), (2) spatial aspects including regional areal size (Rosenzweig and Ziv 1999) and geometric constraints (Bachmann et al. 2004, Grytnes et al. 2008), (3) historical and evolutionary processes (Ricklefs 2004) and (4) biotic processes such as the Rapoport rescue hypothesis (Stevens 1989) or source-sink effects (Grytnes 2003; Kessler et al. 2009). With the exception of area, which usually declines continuously with elevation, all of these factors may be related with hump-shaped species richness patterns. As a result, discrimination between the different potential explanations is difficult. In New Guinea, variation in hump-shaped pattern of palm species richness has been linked to the middomain effect (Bachmann et al. 2004), but the biological reality of this effect is commonly questioned (Currie and Kerr 2008). In our study region, many species overlap in their upper or lower elevational limits at 1000 and $1100 \mathrm{~m}$, which may also increase species richness here, but runs contrary to the assumptions of the mid-domain effect which is based on random species distributions (Herzog et al. 2005; Kluge et al. 2008). The high species richness at mid-elevation could be also related to a lower canopy height (Siebert 2005), because rattan individuals can reach higher light intensities more easily.

The density of rattan palms also exhibited a humped-shaped distribution. Usually, the species richness and density of lianas are highest in tropical lowland forests and decline with elevation (Gentry 1991; Schnitzer and Bongers 2002), although the opposite pattern has also been found (Homeier et al. 2010). In Sarawak, rattan palms are more abundant on ridges than in valleys, contrary to other lianas (Putz and Chai 1987). In Malaysia, rattan palms also reach their highest density at mid-elevations (Appanah et al. 1993). Thus, it appears that the density and richness patterns of rattan palms differ substantially from both patterns of palms and lianas in general.

We didn't find any correlation of mean annual precipitation to species richness or density. Unlike temperature, precipitation in the study region varies not only with elevation but also with locality and topography (Dechert et al. 2004). Furthermore, our elevational transect reaches the regular cloud band commonly found in humid tropical mountains and "horizontal" precipitation may be captured from fog. Unfortunately, no data are available for the study region on this phenomenon. Thus, more detailed measurements are needed to detect any possible relationship of rattan palms to environmental humidity. However, so far correlations between precipitation and rattan palms haven't been found in other studies as well, though some species seem to be adapted to certain soil moisture regimes (Dransfield and Manokaran 1994).

In addition to elevation and closely related climatic parameters, a set of other factors are also likely to influence the species richness and density of rattan palms. Lianas are more diverse and abundant in forests with gaps (Putz 1984; Hegarty and Caballé 1991; Schnitzer and Carson 2001) and most rattan palms establish and grow more rapidly in forest gaps (Appanah and Nor 1991). Montane forests have abundant gaps due to landslides and tree falls (Richards 1996).

Generally, local topography influences the distribution of palms (Kahn 1987), mainly indirectly through factors like soil conditions, disturbances, heterogeneity of the canopy, and biotic interactions (Svenning 2001). Indeed, the distribution of rattan palms in north Sulawesi seems to depend on topography (Clayton et al. 2002). On the other hand, a more detailed survey in our study region only detected a relationship between the slope aspect and community composition of rattan palms, but neither directly with topographic position nor inclination (Getto 2009). Rattan palms occur on most types of rock and soil within their natural distribution area (Dransfield and Manokaran 1994). In fact, differences between 
upper lowland and montane edaphic conditions in our study region do not appear to affect the rattan flora (Siebert 2005).

\section{Elevational ranges of rattan species}

On average, rattan species in our study region had elevational range amplitudes of $515 \mathrm{~m}$. This is likely an underestimate because not all elevations could be sampled and because it is likely that some species were not found in the study plots at elevations where they are not frequent. The gaps within the elevational ranges may likewise reflect the sampling methods which did not account for low population densities. In any case, an elevational range amplitude of $500 \mathrm{~m}$ is in accordance with previously documented range amplitudes of palms (400-1800 m) in Ecuador (Svenning et al. 2009). We observed a marked shift in species composition at around $1000 \mathrm{~m}$, where many lowland species reached their upper and many montane species their lower distributional limits. Only eight species (23\%) were recorded both below and above $1000 \mathrm{~m}$. A similar elevational segregation at around $1000 \mathrm{~m}$ has been found among rattan palms in northern Borneo (Watanabe and Suzuki 2008). The shift from lowland dipterocarp forests to montane oak-laurel forests in Southeast Asia also occurs around $1000 \mathrm{~m}$ (Dransfield 1979), suggesting that this represents a fundamental vegetation limit in the region.

\section{Assemblage composition}

Overall, there was marked turnover in species composition between the study plots. Over half of the 34 rattan species were found in only one or two study sites. We found that elevation was the main factor accounting for shifts in species composition of rattan assemblages. A difference of more than $900 \mathrm{~m}$ in elevation led to a complete species turnover of rattan palms. This agrees well with data on bryophytes, ferns, and angiosperms from other tropical mountains, which typically show changes of about $10 \%$ per $100 \mathrm{~m}$ elevational shift (Kessler 2000a; Bach et al. 2007). In addition, geographical distances between study plots accounted for a considerable proportion in the change of species composition between plots. The similarity of tropical tree assemblages generally tends to decrease with the geographical distance (Condit et al. 2002; Duivenvoorden et al. 2002). This suggests that many rattan palm species have patchy spatial distribution patterns, possibly as a result of varying geological substrates or due to dispersal limitation.

\section{Conclusions}

We found that rattan palms exhibit a distinct hump-shaped elevational pattern in both species richness and density that differs from patterns typically found both for other palms and lianas. Fragmentary data from other sites suggest that this may not only be a local phenomenon of our study area, but more typical of Southeast Asia as a whole.

Importantly, however, commercially important species with long stems of large diameters are largely restricted to elevations below $1000 \mathrm{~m}$. This elevational zone is by far the most heavily impacted by human activities and least protected in LLNP in particular (Erasmi et al. 2004; Schulze et al. 2004; Waltert et al. 2004) and in Southeast Asia in general. Thus, while there are high rattan species numbers and densities at high elevations largely unaffected by human activities, the use of commercially valuable rattan palms is restricted to lowland forests. The long-term effects of intensive, repeated cane harvesting on species richness and densities remain to be determined. While Siebert (2004) recorded 
no mortality of $C$. zollingeri rattans irrespective of cane harvesting intensities and that harvesting stimulated the production of new shoots (i.e., ramets) over four years in southern LLNP, he also found that little harvestable cane (i.e., canes longer than $10 \mathrm{~m}$ ) remained in these forests due to intensive and unregulated harvesting pressure. Furthermore, harvesting effects will vary by species. Rattans capable of vegetative reproduction, such as $C$. zollingeri, may persist longer when subject to intense harvesting than solitary rattans that can only reproduce sexually (i.e., that must flower and fruit), such as C. leptostachys. However, even if rattans capable of vegetative reproduction survive intensive harvesting, they are unlikely to produce mature canes that flower or fruit with potentially significant long-term implications for plant growth and survival.

Sulawesi harbours an abundant and diverse rattan flora due to its complex geology, diverse climatic conditions and extreme elevational gradients. Sampling and taxonomic revision still needs to be done to assess actual species richness of Sulawesi. Future studies should also include long-term monitoring and sustainable management of commercially important rattan populations.

Acknowledgments Field-work was kindly supported by the Collaborative Research Centre SFB 552 STORMA (Stability of Tropical Rainforest Margins) at the University of Göttingen, funded by the German Research Foundation (DFG). We thank the coordination offices in Palu and Göttingen, especially Muhammad Sigit Andhi Rahman and Wolfram Lorenz. We thank the local field assistants and the assistants at the Herbarium of Palu (CEB) who helped in this work, Johanis Mogea for his help at the Herbarium of Bogor (BO), and two anonymous reviewers for comments on the manuscript.

Open Access This article is distributed under the terms of the Creative Commons Attribution Noncommercial License which permits any noncommercial use, distribution, and reproduction in any medium, provided the original author(s) and source are credited.

\section{Appendix}

See Tables 4 and 5.

Table 4 List of rattan palms found the eights study sites in LLNP

\begin{tabular}{|c|c|c|c|c|c|c|c|c|}
\hline Species & Scientific name & Local name & $\begin{array}{l}\text { Growth } \\
\text { form }\end{array}$ & Individuals & Shoots & $\begin{array}{l}\text { Study } \\
\text { sites }\end{array}$ & Transects & Plots \\
\hline 1 & $\begin{array}{l}\text { Calamus } \\
\text { didymocarpus }\end{array}$ & Moli & Clustering & 45 & 188 & 1 & 5 & 26 \\
\hline 2 & $\begin{array}{l}\text { Calamus } \\
\quad \text { kandariensis }\end{array}$ & Putih & Clustering & 107 & 335 & 2 & 15 & 61 \\
\hline 3 & $\begin{array}{l}\text { Calamus } \\
\quad \text { leptostachys }\end{array}$ & $\begin{array}{l}\text { Togisi- } \\
\text { Togisi nona }\end{array}$ & Solitary & 2559 & 2561 & 3 & 21 & 173 \\
\hline 4 & $\begin{array}{l}\text { Calamus } \\
\text { minahassae }\end{array}$ & Tani & Solitary & 32 & 32 & 3 & 10 & 21 \\
\hline 5 & $\begin{array}{c}\text { Calamus ornatus } \\
\text { var. celebicus }\end{array}$ & Lambang & Clustering & 478 & 2053 & 5 & 27 & 159 \\
\hline 6 & $\begin{array}{l}\text { Calamus } \\
\text { symphysipus }\end{array}$ & Ombol & Solitary & 226 & 226 & 3 & 15 & 89 \\
\hline 7 & $\begin{array}{l}\text { Calamus } \\
\text { zollingeri }\end{array}$ & Batang & Clustering & 645 & 3651 & 5 & 27 & 191 \\
\hline 8 & Calamus sp. 1 & Tohiti-Asli & Solitary & 213 & 213 & 2 & 3 & 20 \\
\hline
\end{tabular}


Table 4 continued

\begin{tabular}{|c|c|c|c|c|c|c|c|c|}
\hline Species & Scientific name & Local name & $\begin{array}{l}\text { Growth } \\
\text { form }\end{array}$ & Individuals & Shoots & $\begin{array}{l}\text { Study } \\
\text { sites }\end{array}$ & Transects & Plots \\
\hline 9 & Calamus sp. 2 & Uban & Solitary & 7 & 7 & 3 & 3 & 5 \\
\hline 10 & Calamus sp. 3 & Botol & Solitary & 518 & 518 & 2 & 11 & 67 \\
\hline 11 & Calamus sp. 4 & Tohiti & Solitary & 53 & 53 & 1 & 3 & 12 \\
\hline 12 & Calamus sp. 5 & $\begin{array}{l}\text { Pahit- } \\
\text { Humampu }\end{array}$ & Clustering & 1032 & 2058 & 3 & 17 & 128 \\
\hline 13 & Calamus sp. 6 & $\begin{array}{l}\text { Tohiti nona- } \\
\text { Manda }\end{array}$ & Solitary & 78 & 78 & 2 & 7 & 33 \\
\hline 14 & Calamus sp. 7 & Tohiti & Solitary & 160 & 160 & 2 & 4 & 23 \\
\hline 15 & Calamus sp. 8 & Tohiti & Solitary & 2 & 2 & 1 & 1 & 1 \\
\hline 16 & Calamus sp. 9 & Botol asli & Solitary & 150 & 150 & 2 & 8 & 24 \\
\hline 17 & Calamus sp. 10 & $\begin{array}{c}\text { Tohiti batu- } \\
\text { Patani- } \\
\text { Kuruku }\end{array}$ & Solitary & 150 & 150 & 4 & 10 & 44 \\
\hline 18 & Calamus sp. 11 & Uban & Solitary & 103 & 103 & 2 & 5 & 20 \\
\hline 19 & Calamus sp. 12 & $\begin{array}{l}\text { Leilolo- } \\
\text { Ronti-Kuru }\end{array}$ & Solitary & 8 & 10 & 3 & 6 & 8 \\
\hline 20 & Calamus sp. 13 & Tohiti asli & Solitary & 166 & 166 & 1 & 4 & 16 \\
\hline 21 & Calamus sp. 14 & Uban & Solitary & 148 & 148 & 1 & 3 & 28 \\
\hline 22 & Calamus sp. 15 & Datuk & Clustering & 76 & 196 & 1 & 4 & 20 \\
\hline 23 & Calamus sp. 16 & $\begin{array}{l}\text { Kalaka- } \\
\text { Mpowaloa- } \\
\text { Pait }\end{array}$ & Solitary & 623 & 623 & 4 & 12 & 54 \\
\hline 24 & Calamus sp. 17 & Nkaruku & Solitary & 49 & 49 & 2 & 6 & 19 \\
\hline 25 & Calamus sp. 18 & Ronti & Clustering & 1 & 1 & 1 & 1 & 1 \\
\hline 26 & Calamus sp. 19 & Ruru & Clustering & 2 & 2 & 1 & 2 & 2 \\
\hline 27 & Calamus sp. 20 & Nona & Solitary & 2 & 2 & 1 & 2 & 2 \\
\hline 28 & Calamus sp. 21 & Noko II & Solitary & 261 & 261 & 2 & 6 & 28 \\
\hline 29 & Calamus sp. 22 & Putih_-Hilako & Solitary & 245 & 245 & 2 & 4 & 26 \\
\hline 30 & Calamus sp. 23 & Paloe & Solitary & 34 & 34 & 1 & 2 & 8 \\
\hline 31 & Calamus sp. 24 & Uwe koi & Clustering & 102 & 122 & 1 & 3 & 15 \\
\hline 32 & $\begin{array}{c}\text { Daemonorops } \\
\text { macroptera }\end{array}$ & Noko & Clustering & 380 & 1710 & 5 & 25 & 167 \\
\hline 33 & $\begin{array}{l}\text { Daemonorops sp. } \\
\quad 1\end{array}$ & Noko ibo & Solitary & 297 & 297 & 3 & 15 & 70 \\
\hline 34 & $\begin{array}{r}\text { Korthalsia } \\
\text { celebica }\end{array}$ & Tahik manuk & Clustering & 44 & 170 & 3 & 7 & 27 \\
\hline
\end{tabular}

Table 5 Observed species richness and estimated species richness after Chao (1987) for all 50 plots

\begin{tabular}{lllllll}
\hline Transect & $\begin{array}{l}\text { Elevation } \\
(\mathrm{m})\end{array}$ & $\begin{array}{l}\text { No. of } \\
\text { species }\end{array}$ & Chao 1 & $\begin{array}{l}\text { No of. species/ } \\
\text { Chao 1 }(\%)\end{array}$ & Chao 2 & $\begin{array}{l}\text { No of. species/ } \\
\text { Chao 2 }(\%)\end{array}$ \\
\hline 1 & 250 & 2 & 2 & 100 & 2 & 100 \\
2 & 260 & 1 & 1 & 100 & 1 & 100 \\
3 & 300 & 2 & 2 & 100 & 2 & 100 \\
4 & 340 & 1 & 1 & 100 & 1 & 100 \\
\hline
\end{tabular}


Table 5 continued

\begin{tabular}{|c|c|c|c|c|c|c|}
\hline Transect & $\begin{array}{l}\text { Elevation } \\
(\mathrm{m})\end{array}$ & $\begin{array}{l}\text { No. of } \\
\text { species }\end{array}$ & Chao 1 & $\begin{array}{l}\text { No of. species/ } \\
\text { Chao } 1(\%)\end{array}$ & Chao 2 & $\begin{array}{l}\text { No of. species/ } \\
\text { Chao } 2(\%)\end{array}$ \\
\hline 5 & 580 & 6 & 8 & 75 & 8 & 75 \\
\hline 6 & 715 & 4 & 4 & 100 & 4 & 100 \\
\hline 7 & 725 & 7 & 7 & 100 & 7 & 100 \\
\hline 8 & 785 & 5 & 5 & 100 & 5 & 100 \\
\hline 9 & 810 & 7 & 7 & 100 & 7 & 100 \\
\hline 10 & 860 & 6 & 8 & 75 & 6.3 & 96 \\
\hline 11 & 890 & 14 & 16.3 & 86 & 18.5 & 76 \\
\hline 12 & 910 & 6 & 6 & 100 & 6 & 100 \\
\hline 13 & 920 & 8 & 8.5 & 94 & 8 & 100 \\
\hline 14 & 925 & 7 & 7.5 & 93 & 7 & 100 \\
\hline 15 & 930 & 10 & 10 & 100 & 10 & 100 \\
\hline 16 & 955 & 10 & 12 & 83 & 10 & 100 \\
\hline 17 & 965 & 6 & 6 & 100 & 6 & 100 \\
\hline 18 & 975 & 5 & 5 & 100 & 5 & 100 \\
\hline 19 & 980 & 7 & 8 & 88 & 7.5 & 93 \\
\hline 20 & 1010 & 10 & 10 & 100 & 10 & 100 \\
\hline 21 & 1020 & 11 & 13.3 & 83 & 11.3 & 98 \\
\hline 22 & 1025 & 10 & 12 & 83 & 10 & 100 \\
\hline 23 & 1030 & 11 & 11 & 100 & 11 & 100 \\
\hline 24 & 1030 & 7 & 7.5 & 93 & 7 & 100 \\
\hline 25 & 1040 & 9 & 9.5 & 95 & 9.5 & 95 \\
\hline 26 & 1050 & 8 & 8 & 100 & 8 & 100 \\
\hline 27 & 1090 & 9 & 17 & 53 & 13.5 & 67 \\
\hline 28 & 1090 & 10 & 12.3 & 82 & 10 & 100 \\
\hline 29 & 1200 & 4 & 4 & 100 & 4 & 100 \\
\hline 30 & 1200 & 6 & 6 & 100 & 6 & 100 \\
\hline 31 & 1220 & 5 & 5.5 & 91 & 5 & 100 \\
\hline 32 & 1250 & 4 & 4.5 & 89 & 4 & 100 \\
\hline 33 & 1250 & 6 & 8 & 75 & 6 & 100 \\
\hline 34 & 1400 & 6 & 6 & 100 & 6 & 100 \\
\hline 35 & 1400 & 7 & 9 & 78 & 7.5 & 93 \\
\hline 36 & 1430 & 7 & 7 & 100 & 7 & 100 \\
\hline 37 & 1450 & 5 & 5 & 100 & 5 & 100 \\
\hline 38 & 1450 & 6 & 6.5 & 92 & 6.5 & 92 \\
\hline 39 & 1470 & 5 & 5.5 & 91 & 5.5 & 91 \\
\hline 40 & 1480 & 6 & 6 & 100 & 6 & 100 \\
\hline 41 & 1800 & 5 & 5 & 100 & 5 & 100 \\
\hline 42 & 1820 & 5 & 5 & 100 & 5 & 100 \\
\hline 43 & 1880 & 1 & 1 & 100 & 1 & 100 \\
\hline 44 & 1880 & 4 & 4 & 100 & 6 & 67 \\
\hline 45 & 2170 & 4 & 4 & 100 & 4.5 & 89 \\
\hline 46 & 2170 & 3 & 3.5 & 86 & 3 & 100 \\
\hline 47 & 2380 & 2 & 2.5 & 80 & 2.5 & 80 \\
\hline
\end{tabular}


Table 5 continued

\begin{tabular}{lllllll}
\hline Transect & $\begin{array}{l}\text { Elevation } \\
(\mathrm{m})\end{array}$ & $\begin{array}{l}\text { No. of } \\
\text { species }\end{array}$ & Chao 1 & $\begin{array}{l}\text { No of. species/ } \\
\text { Chao 1 }(\%)\end{array}$ & Chao 2 & $\begin{array}{l}\text { No of. species/ } \\
\text { Chao 2 }(\%)\end{array}$ \\
\hline 48 & 2380 & 2 & 2 & 100 & 2 & 100 \\
49 & 2420 & 1 & 1 & 100 & 1 & 100 \\
50 & 2420 & 1 & 1 & 100 & 1 & 100 \\
\hline
\end{tabular}

On average 95\% (Chao 1: 93\%, Chao 2: 96\%) of estimated species richness was found in the plots

\section{References}

Appanah S, Nor SM (1991) Natural regeneration and its implications for forest management in the dipterocarp forests of Peninsular Malaysia. In: Gómez-Pompa A, Whitmore TC, Hadley M (eds) Rain forest regeneration and management. Man and biosphere series No. 6. UNESCO, Paris, pp 361-369

Appanah S, Gentry AH, LaFrankie JV (1993) Liana diversity and species richness of Malaysian rain forests. J Trop For Sci 6:116-123

Bach K, Kessler M, Gradstein SR (2007) A simulation approach to determine statistical significance of species turnover peaks in a species-rich tropical cloud forest. Divers Distrib 13:863-870

Bachmann S, Baker WJ, Brummitt N et al (2004) Elevational gradients, area and tropical island diversity: an example from the palms of New Guinea. Ecography 27:299-310

Balfour DA, Bond WJ (1993) Factors limiting climber distribution and abundance in a southern African forest. J Ecol 81:93-100

Bhattarai KR, Vetaas OR, Grytnes JA (2004) Fern species richness along a central Himalayan elevational gradient, Nepal. J Biogeogr 31:389-400

Bøgh A (1996) Abundance and growth of rattans in Khao Chong National Park, Thailand. For Ecol Manage $84: 71-80$

Cannon CH, Summers M, Harting JR et al (2007) Developing conservation priorities based on forest type, condition, and threats in a poorly known ecoregion: Sulawesi, Indonesia. Biotropica 39:747-759

Chao A (1987) Estimating the population size for capture-recapture data with unequal catchability. Biometrics 43:783-791

Clayton LM, Milner-Gulland EJ, Sarjono AP (2002) Sustainability of rattan harvesting in North Sulawesi, Indonesia. In: Maunder M, Clubbe $\mathrm{C}$, Hankamer $\mathrm{C}$ et al (eds) Plant conservation in the tropics: perspectives and practice. Royal Botanic Gardens, Kew, pp 445-466

Condit R, Pitman N, Leigh Jr et al (2002) Beta-diversity in tropical forest trees. Science 295:666-669

Culmsee H, Pitopang R (2009) Tree diversity in sub-montane and lower montane primary rain forests in Central Sulawesi. Blumea 54:119-123

Currie DJ, Kerr JT (2008) Tests of the mid-domain hypothesis: a review of the evidence. Ecol Monogr $78: 3-18$

Currie DJ, Mittelbach GG, Cornell HV et al (2004) Predictions and tests of climate-based hypotheses of broad-scale variation in taxonomic richness. Ecol Lett 7:1121-1134

Dechert G, Veldkamp E, Anas I (2004) Is soil degradation unrelated to deforestation? Examining soil parameters of land use systems in upland Central Sulawesi, Indonesia. Plant Soil 265:197-209

Dransfield J (1979) A manual of the rattans of the Malay Peninsula. Malayan Forest Records No. 29, Forest Department, Kuala Lumpur

Dransfield J (1984) The rattans of Sabah. Forest Department, Sabah

Dransfield J (1992) The rattans of Sarawak. Royal Botanic Gardens, Kew, Sarawak Forest Department

Dransfield J (1997) The rattans of Brunei Darussalam. Forestry Department, Royal Botanic Gardens, Brunei Darussalam, Kew

Dransfield J (2001) Taxonomy, biology and ecology of rattan. Unasylva 52:11-13

Dransfield J, Manokaran N (eds) (1994) Plant resources of South-East Asia, Rattans, no. 6. Prosea Foundation, Bogor

Duivenvoorden JF, Svenning J-C, Wright SJ (2002) Beta diversity in tropical forests. Science 295:636-637

Erasmi S, Twele A, Ardiansyah M et al (2004) Mapping deforestation and land cover conversion at the rainforest margin in Central Sulawesi, Indonesia. Eur Assoc Remote Sens Lab eProc 3:388-397

Gentry AH (1991) The distribution and evolution of climbing plants. In: Putz FE, Mooney HA (eds) The biology of vines. Cambridge University Press, Cambridge, pp 3-49 
Getto D (2009) Einfluss von Waldstruktur, Topographie, Bodenparametern und Raum auf die Gemeinschaftszusammensetzung von Rattan-Arten (Arecaceae) im Lore Lindu Nationalpark, Sulawesi, Indonesien. Bachelor thesis, University of Göttingen

Grytnes JA (2003) Species-richness patterns of vascular plants along seven altitudinal transects in Norway. Ecography 26:291-300

Grytnes JA, Beaman JH, Romdal TS et al (2008) The mid-domain effect matters: simulation analyses of range-size distribution data from Mount Kinabalu, Borneo. J Biogeogr 35:2138-2147

Hawkins BA, Field R, Cornell HV et al (2003) Energy, water, and broad-scale geographic patterns of species richness. Ecol 84:3105-3117

Hegarty EE, Caballé G (1991) Distribution and abundance of vines in forest communities. In: Putz FE, Mooney HA (eds) The biology of vines. Cambridge University Press, Cambridge, pp 313-335

Herzog SK, Kessler M, Bach K (2005) The elevational gradient in Andean bird species richness at the local scale: a foothill peak and a high-elevation plateau. Ecography 28:209-222

Hijmans RJ, Cameron SE, Parra JL et al (2006) The WorldClim interpolated global terrestrial climate surfaces, Version 1.4. http://www.worldclim.org

Homeier J, Englert F, Leuschner C et al (2010) Factors controlling the abundance of lianas along an altitudinal transect of tropical forests in Ecuador. For Ecol Manage 259:1399-1405

Kahn F (1987) The distribution of palms as a function of local topography in Amazonian terra-firme forests. Experientia 43:251-259

Kessler M (2000a) Altitudinal zonation of Andean cryptogam communities. J Biogeogr 27:275-282

Kessler M (2000b) Elevational gradients in species richness and endemism of selected plant groups in the central Bolivian Andes. Plant Ecol 149:181-193

Kessler M (2001a) Pteridophyte species richness in Andean forests in Bolivia. Biodivers Conserv 10:1473-1495

Kessler M (2001b) Patterns of diversity and range size of selected plant groups along an elevational transect in the Bolivian Andes. Biodivers Conserv 10:1897-1921

Kessler M, Keßler PJA, Gradstein SR et al (2005) Tree diversity in primary forest and different land use systems in Central Sulawesi, Indonesia. Biodivers Conserv 14:547-560

Kessler M, Abrahamczyk S, Bos M et al (2009) Alpha and beta diversity of plants and animals along a tropical land-use gradient. Ecol Appl 19:2142-2156

Kluge J, Kessler M, Dunn RR (2006) What drives elevational patterns of diversity? A test of geometric constraints, climate and species pool effects for pteridophytes on an elevational gradient in Costa Rica. Global Ecol Biogeogr 15:358-371

Kluge J, Bach K, Kessler M (2008) Elevational distribution and zonation of tropical pteridophyte assemblages in Costa Rica. Basic Appl Ecol 9:35-43

Legendre P, Legendre L (1998) Numerical Ecology, vol 2. Elsevier, Amsterdam, pp 557-558

McCain CM (2009) Global analysis of bird elevational diversity. Global Ecol Biogeogr 18:346-360

McCune B, Mefford MJ (1999) PC-ORD: multivariate analysis of ecological data. Version 5.0. MjM Software, Gleneden Beach

Oksanen J, Kindt R, Legendre P et al (2008) Vegan: community ecology package. R package version 1.16-2. http://www.vegan.r-forge.r-project.org

Putz FE (1984) The natural history of lianas on Barro Colorado Island, Panama. Ecol 65:1713-1724

Putz FE, Chai P (1987) Ecological studies of lianas in Lambir National Park, Sarawak, Malaysia. J Ecol 75:523-531

Richards PW (1996) The tropical rain forest, vol 2. Cambridge University Press, Cambridge

Ricklefs RE (2004) A comprehensive framework for global patterns in biodiversity. Ecol Lett 7:1-15

Rosenzweig ML, Ziv Y (1999) The echo pattern of species diversity: pattern and processes. Ecography 22:614-628

Ros-Tonen MAF (2000) The role of non-timber forest products in sustainable tropical forest management. Holz Roh Werkst 58:196-201

Schnitzer SA, Bongers F (2002) The ecology of lianas and their role in forests. Trends Ecol Evol 17:223-230

Schnitzer SA, Carson WP (2001) Treefall gaps and the maintenance of species diversity in a tropical forest. Ecol 82:913-919

Schulze CH, Waltert M, Keßler PJA et al (2004) Biodiversity indicator groups of tropical land-use systems: comparing plants, birds, and insects. Ecol Appl 14:1321-1333

Siebert SF (1993) The abundance and site preferences of rattan (Calamus exilis and Calamus zollingeri) in two Indonesian national parks. For Ecol Manage 59:105-113

Siebert SF (1998) Rattan use, economics, ecology, and management in the southern Lore Lindu National Park region of Sulawesi, Indonesia. Final report: Rattan micro-enterprise component. Biodiversity Conservation Network Project, The Nature Conservancy, Jakarta 
Siebert SF (2000) Survival and growth of rattan intercropped with coffee and cacao in the agroforests of Indonesia. Agroforest Syst 50:95-102

Siebert SF (2001) Tree cutting to float rattan to market: a threat to primary forests? J Bamboo Rattan $1: 37-42$

Siebert SF (2004) Demographic effects of collecting rattan cane and their implications for sustainable harvesting. Conserv Biol 18:424-431

Siebert SF (2005) The abundance and distribution of rattan over an elevation gradient in Sulawesi, Indonesia. For Ecol Manage 210:143-158

Stevens GC (1989) The latitudinal gradient in geographical range: how so many species coexist in the tropics. Am Nat 133:240-256

Sunderland TCH, Dransfield J (2002) Species profile rattan. In: Dransfield J, Tesoro FO, Manokaran N (eds) Rattan: current research issues and prospects for conservation and sustainable development. NonWood Forest Products 14. FAO, Rome, pp 9-22

Svenning J-C (2001) On the role of microenvironmental heterogeneity in the ecology and diversification of neotropical rain-forest palms (Arecaceae). Bot Rev 67:1-53

Svenning J-C, Harlev D, Sørensen MM, Balslev H (2009) Topographic and spatial controls of palm species distributions in a montane rain forest, southern Ecuador. Biodivers Conserv 18:219-228

The Nature Conservancy (2001) Lore Lindu National Park, park profile. http://www.nature.org/ wherewework/asiapacific/indonesia/files/lore_lindu_summary.pdf

Tomlinson PB (2006) The uniqueness of palms. Bot J Linn Soc 151:5-14

Uhl NW, Dransfield J (1987) Genera Palmarum: a classification of palms based on the work of Harold EM Jr Lawrence. Allen Press, Kansas

Waltert M, Langkau M, Maertens M et al (2004) Predicting losses of bird species from deforestation in Central Sulawesi. In: Gerold G, Fremerey M, Guhardja E (eds) Land use nature conservation and the stability of rainforest margins in Southeast Asia. Springer, Berlin Heidelberg, pp 327-349

Watanabe NM, Suzuki E (2008) Species diversity, abundance, and vertical size structure of rattans in Borneo and Java. Biodivers Conserv 17:523-538 